\title{
United States non-cooperation and the Paris agreement
}

\section{Johannes Urpelainen \& Thijs Van de Graaf}

To cite this article: Johannes Urpelainen \& Thijs Van de Graaf (2017): United States noncooperation and the Paris agreement, Climate Policy, DOI: 10.1080/14693062.2017.1406843

To link to this article: https://doi.org/10.1080/14693062.2017.1406843

$$
\text { 曲 Published online: } 15 \text { Dec } 2017 .
$$

Submit your article to this journal $[\pi$

Q View related articles

View Crossmark data $\nearrow$ 


\title{
United States non-cooperation and the Paris agreement
}

\author{
Johannes Urpelainen ${ }^{\mathrm{a}}$ and Thijs Van de Graaf $\mathbb{B}^{\mathrm{b}}$ \\ aJohns Hopkins School of Advanced International Studies, Washington, DC, USA; ${ }^{b}$ Institute for International Studies, Ghent \\ University, Gent, Belgium
}

\begin{abstract}
In June 2017, the Trump administration decided to withdraw the US from the Paris Agreement, a landmark climate agreement adopted in 2015 by 195 nations. The exit of the US has not just raised concern that the US will miss its domestic emission reduction targets, but also that other parties to the Paris Agreement might backtrack on their initial pledges regarding emission reductions or financial contributions. Here we assess the magnitude of the threat that US non-cooperation poses to the Paris Agreement from an international relations perspective. We argue that US non-cooperation does not fundamentally alter US emissions, which are unlikely to rise even in the absence of new federal climate policies. Nor does it undermine nationally determined contributions under pledge and review, as the Paris Agreement has introduced a new logic of domestically driven climate policies and the cost of low-carbon technologies keeps falling. However, US nonparticipation in raising climate finance could raise high barriers to global climate cooperation in the future. Political strategies to mitigate these threats include direct engagement by climate leaders such as the European Union with key emerging economies, notably China and India, and domestic climate policies that furnish benefits to traditional opponents of ambitious climate policy.

\section{Key policy insights}

- US non-cooperation need not be a major threat to pledge and review under the Paris Agreement.

- US non-cooperation is a serious threat to climate finance.

- Deeper engagement with emerging economies offers new opportunities for global climate policy.
\end{abstract}

\section{ARTICLE HISTORY}

Received 23 June 2017

Accepted 14 November 2017

\section{KEYWORDS}

International cooperation; climate negotiations; leadership; United States

\section{Introduction}

On 8 November 2016, Donald J. Trump won the presidential election in the US. Trump's rhetoric during the campaign, his cabinet appointments and his first acts since taking office have made it abundantly clear that there will be no US climate leadership during his tenure (Bomberg, 2017; Mehling, 2017). Most notably, in March 2017, President Trump signed an executive order to reverse his predecessor's policies to reduce US greenhouse gas emissions (White House, 2017b). Then, on 1 June 2017, he announced the US withdrawal from the Paris Agreement, a process that (because of stipulations in the treaty) would take four years to complete.

The Trump era is not the first time the US has adopted a hostile posture toward multilateral climate cooperation. The tenure of President George W. Bush between the years 2001 and 2008 was a difficult time in climate cooperation. The Bush administration's refusal to ratify the Kyoto Protocol dealt a significant blow to the treaty, despite its eventual entry into force in 2005. Continued US opposition to ambitious targets for emission reductions also complicated the negotiations for a post-Kyoto climate regime. Major emerging economies, led by China and India, found US inaction a convenient cover for their own growing emissions (Clémençon, 2008, p. 71). 
Understanding the impact of US non-cooperation on international climate policy under the Paris Agreement is absolutely vital. For one thing, the US is the world's second largest emitter and one of its wealthiest nations. In 2013, the US was responsible for $13.7 \%$ of greenhouse gas (GHG) emissions, including those from land-use change and forestry (WRI, 2017). For another, Trump does not stand alone with his anti-climate change programme. In Germany, the right-wing Alternative for Germany (AfD) seeks to withdraw from all climate agreements including their financial obligations. ${ }^{2}$ Geert Wilders, leader of the Dutch right-wing Freedom Party (PVV), is a notorious denier of anthropogenic climate change. In France, Le Pen's National Front party has described the UNFCCC as a 'communist project'.

This article provides a contribution to the proliferating and important literature on US non-cooperation in environmental policy. A key point across this literature is that US non-cooperation is largely a structural issue, related to the particularities of the US political system, which make it hard for US presidents to adopt environmental regulations or ratify multilateral agreements (Bang, Hovi, \& Sprinz, 2012; Depledge, 2005; DeSombre, 2000; Kemp, 2016). Most of these studies date from before the election of Trump and his formal decision to withdraw from the Paris Agreement. Kemp (2017b) deserves credit for anticipating the US exit from Paris and exploring legal options to deal with a US non-party, including allowing the inclusion of individual US states. However, assessing the full effects of Trump's policies and actions can only be done ex post.

Our goal here is to assess the extent to which climate cooperation under the Paris Agreement is threatened by President Trump's hostile views of the regime and, to the extent there is a real threat, to consider protective measures. We use the term non-cooperation to denote any situation in which a country is not engaging constructively in the global climate regime. A continuum rather than a binary, the term covers the possibilities of active opposition and resistance to the goals of international climate policy, or simple lack of any meaningful action to curb emissions and help developing countries. Non-cooperation should not be conflated with legal withdrawal. Even if the US had not announced its withdrawal from the Paris Agreement, the Trump administration could still have reversed many domestic climate policies, since the Paris Agreement has no binding requirements regarding actual emissions levels (Bordoff, 2017). Worse, a recalcitrant US could have acted as a regime spoiler from within the Paris Agreement, e.g. by obstructing the negotiations on the 'Paris rulebook' (Kemp, 2017a). Nor is non-cooperation a unique US feature. Australia, an industrialized country, is currently on track to significantly increase its domestic emissions and miss its pledge while opening new coal mines (Climate Action Tracker, 2017a). To a certain degree, this can also be classified as non-cooperation.

Our central argument is that US non-cooperation does not present a major threat to US emissions, which might keep falling regardless of federal policy. Nor does it undermine increasingly ambitious emission reductions around the world, as the Paris Agreement has introduced a new logic of domestically driven climate policy while the cost of low-carbon technologies has come down significantly. A more serious threat is found in US non-participation in climate financing, particularly with regard to the capitalization of the Green Climate Fund (GCF). We suggest two opportunities to mitigate the effects of US non-cooperation: (i) the European Union, China and India could step up to replace US climate leadership and (ii) domestic coalitions of citizens, municipalities, businesses and other actors that are in favour of climate change could be entrenched through targeted policies and framing, so that climate policies worldwide become more resilient to electoral cycles and shocks.

In the next section, we summarize the literature on leadership in climate policy and apply it to the case of the US. We then discuss how US non-cooperation would shape international negotiations and domestic policies. The last section emphasizes the importance of engaging with emerging economies and dealing with domestic political uncertainty for the future of the Paris Agreement.

\section{US climate leadership under Obama}

To assess the effects of US non-cooperation on the Paris Agreement, our baseline assumption is that the US played a leadership role under the Obama administration. At least four types of leadership can be distinguished in international environmental negotiations. Power-based leadership achieves outcomes by deploying threats and promises. For example, the economic might and financial resources of the US mean that a proactive President could entice emerging economies to participate with promises of climate finance (Ghosh \& Woods, 2009) or, in an extreme scenario, the threat of carbon tariffs (Weber \& Peters, 2009). Directional leadership is 
based on a positive example that encourages others to follow, such as demonstrating the feasibility of renewable energy or clean technology development (Urpelainen, 2011). Entrepreneurial leadership refers to the leader's skilful activities in negotiations. For example, the US President might broker deals or build coalitions that help to produce better cooperation outcomes. Intellectual leadership, finally, involves the production and promotion of new ideas and solutions (Andresen \& Agrawala, 2002; Skodvin \& Andresen, 2006; Young, 1991).

The US position on climate change has oscillated considerably over time between phases of active leadership and phases of passivity (Bang \& Schreurs, 2016). Even though the US had long displayed intellectual leadership in sponsoring scientific research on climate change, and it played a key role in the establishment of the International Panel on Climate Change (IPCC) in 1988, it only reluctantly agreed to launch negotiations on a climate change convention and subsequently resisted efforts to establish emission targets (Depledge, 2005).

Under the Clinton-Gore administration, the US conceded to negotiate binding emission reduction targets, while it kept pressing for flexibility mechanisms, including international emissions trading (Harrison, 2007). The election of a Republican-dominated Congress in late 1994 meant that domestic opposition was strong to binding targets and timetables, largely out of fear that US firms would lose their competitiveness on global markets. The US signed the Kyoto Protocol in late 1998, but the Clinton administration did not present the Kyoto Protocol to the Senate for ratification and, in 2001, the freshly elected Bush administration announced that it would not ratify Kyoto. This provided an opportunity for the European Union to take on a position of leadership on climate change (Schreurs \& Tiberghien, 2007).

Still, the Bush administration was keen on legitimizing its absence from Kyoto by pursuing an alternative, mostly voluntary, technology-driven strategy (Eckersley, 2007). It assumed an entrepreneurial leadership role in setting up narrowly focused regimes and clubs outside of the UNFCCC, including the Asia-Pacific Partnership in 2005, the Major Economies Meeting in 2007 and a host of technology-oriented partnerships (De Coninck, Fischer, Newell, \& Ueno, 2008; Lesage, Van de Graaf, \& Westphal, 2010), thus contributing to the fragmentation of the global climate regime (Keohane \& Victor, 2011).

With the 2008 election of Obama, the US re-engaged in the multilateral climate change negotiations. It signed onto the Copenhagen Accord of 2009 and the Paris Agreement of 2015, while also presenting voluntary pledges to reduce emissions. Yet, the idiosyncrasies of the US political system have continued to hamper efforts to reassert US climate leadership (Kemp, 2016; Paterson, 2009), pushing the Obama administration to pursue less traditional political strategies in climate policy (Bang \& Schreurs, 2016; Skodvin \& Andresen, 2009). The US showed it can rapidly reduce its emissions, even without agreeing to binding emission reduction targets. US carbon emissions from the energy sector seem to have peaked in 2007 and had declined by $14 \%$ by the end of 2016, thanks to a host of factors such as the Great Recession but also increasingly the shift from coal to natural gas and wind in the electric power sector (Feng, Davis, Sun, \& Hubacek, 2015; Hausfather, 2017). In the same period, China's emissions rose by almost $40 \%$ and India's emissions even by as much as $45 \%$ (WRI, 2017). The Obama administration also engaged in entrepreneurial leadership through bilateral diplomacy, and particularly its outreach to China. The US-China agreement of November 2014 was an important catalyst that generated momentum for achieving the Paris Agreement (Dimitrov, 2016; White House, 2014). ${ }^{4}$

\section{The impacts of US non-cooperation}

The Trump administration's policies clearly constitute a move from Obama-era leadership. For international climate policy, US non-cooperation poses at least three different threats: (i) the US might miss its domestic emission reduction pledges; (ii) other parties might water down their commitments in return, undermining the pledge-and-review system which is supposed to ratchet up emission reduction targets over time and (iii) the lack of US contributions might undermine climate finance. ${ }^{5}$ Of the three threats, the threat to climate finance is the most severe.

\subsection{Missing emission pledges}

The US has set near-term targets to reduce GHG emissions by $17 \%$ by 2020 (pledge made under the Copenhagen Accord) and $26-28 \%$ by 2025 (nationally determined contribution, or NDC, as submitted to the Paris 
Agreement), with both goals defined relative to 2005 levels (United States, 2015). As required under the Paris Agreement, the US has presented a mid-century strategy that envisions economy-wide net GHG emissions' reductions of $80 \%$ or more below 2005 levels by 2050 (White House, 2016).

The Clean Power Plan was the single most important element of the Obama administration's climate strategy, in support of its Paris pledge. It aimed to cut $\mathrm{CO}_{2}$ emissions from power plants by $32 \%$ below 2005 levels by 2030. However, the US NDC has been criticized for being at the least ambitious end of what would be a fair contribution to the Paris goals of limiting global warming to well below $2^{\circ} \mathrm{C}$ (Climate Action Tracker, 2017b), so the Paris goals were always contingent on other parties making a comparably greater effort. Moreover, by the end of Obama's tenure, it was clear that existing federal climate policies were not going to deliver the pledged emissions reduction by 2025 (Greenblatt \& Wei, 2016).

As mentioned, in March 2015, President Trump signed an Executive Order to rescind the Clean Power Plan (White House, 2017b). But even in the absence of the Clean Power Plan, US emissions are unlikely to increase. A recent analysis by the Climate Action Tracker notes that Trump's cancellation of the Clean Power Plan would leave US emissions roughly at today's levels in 2025 and 2030, as sub-national climate policies and the declining competitiveness of coal in power generation prevent rapid emission increases (CAT, 2017). Galik, Decarolis, \& Fell (2017) similarly find that emission declines in the energy sector are likely to continue, regardless of Trump's dismantling of federal climate policies, but they note that emissions in the land use and built environment sector are subject to considerable uncertainty.

In short, it is unlikely that Trump's actions to date will reverse key trends in US emissions: they are flat or in decline, but not fast enough to meet the US pledge, which itself was inadequate to realize the Paris goals. These elements have not changed since Trump took office, though his anti-climate policies have obviously made things worse. Any reductions in US emissions under the current administration are likely to be minor, and US emissions are still completely at odds with what would be a fair share of global effort to keep global warming below $2^{\circ} \mathrm{C}$ (Climate Action Tracker, 2017b).

It is also likely that US states, cities and businesses will contribute to filling any gap left by federal inaction. States such as California - the world's sixth largest economy if it was a sovereign state ${ }^{6}$ - have in the past shown their ability to reduce their emissions with aggressive policies even in the absence of federal support (Rabe, 2004; Urpelainen, 2009). Although the effectiveness of sub-national policy has varied widely and sometimes amounted to little more than window dressing, key state policies such as renewable portfolio standards have proven their effectiveness in the US (Barbose et al., 2016). Besides states, both municipalities and companies have also shown a marked willingness to 'experiment' with new climate policies (Hoffmann, 2011). Scholars such as Hale (2011) have proposed that such actors around the world could constitute a 'climate coalition of the willing' and make a substantial contribution to emission reductions, regardless of the choices of national authorities. The surge of non-state climate action can further reduce the vulnerability of the pledge-andreview system to US non-cooperation. If the federal government remains inactive in the face of climate change, ambitious climate action at lower levels of government can reassure other governments, and nonstate actors outside the US to continue their efforts to reduce emissions.

\subsection{Undermining pledge and review}

Globally, Trump's policies could cause a delay in mitigation that could render the $2^{\circ} \mathrm{C}$ target unachievable if a global precedent is set (Sanderson \& Knutti, 2016), which brings us to the pledge-and-review system. The pledge-and-review system of the Paris Agreement is based on regular - typically every five years - reviews and updates of the parties' NDCs. US non-participation would certainly present a grave threat to other parties' willingness to ratchet up their contributions if these contributions were based on the logic of reciprocity, so that other countries increase their contributions to entice the US to contribute more.

However, this is not the case. The Paris Agreement is built on the notion of domestically driven climate action, which allows countries to determine their mitigation efforts independently and voluntarily (Falkner, 2016). As a result, countries' NDCs reflect a variety of domestic considerations including public opinion, the co-benefits of climate action (e.g. air pollution and energy security), and efforts to build globally competitive clean technology industries. US non-participation does not by any means reduce the weight of these considerations. To the 
contrary, it offers an opportunity for other countries to pull ahead in the race to develop the energy technologies of tomorrow (Bordoff, 2017).

The pledge-and-review process relies on peer pressure and 'naming and shaming' tactics to create a positive spiral of increased ambition over time, which is needed to deliver on long-term climate stabilization goals (Falkner, 2016). While countries may find it advantageous to be seen as global leaders, these reputational incentives are unlikely to override conflicting domestic interests. For example, the US stood firm in its decision not to ratify Kyoto despite facing universal condemnation (Eckersley, 2007). The US is so far the only country to walk away from the Paris Agreement, and the risk that this sets in motion a domino effect of other countries scaling down their pledges hinges entirely on how the US exit alters the domestic calculations that now primarily drive national climate policies. Rather than triggering a downward spiral of lower ambition, the US exit might actually inspire other countries to step up their game and assume global climate leadership, while reaping the soft power benefits that come with it. Indeed, Canada has already increased its contributions to the IPCC to make up for the loss of US funding (Environment and Climate Change Canada, 2017).

In addition, and as noted above, US emissions are a decreasing share of the world total. Emissions in the US trend downward in the long run, with carbon-intensive coal being initially replaced by natural gas and ultimately renewable power: even without any new policies at all, US emissions would probably not grow. Therefore, other countries have little reason to worry that US non-participation would result in a sharp increase in US emissions the drivers of US emission reductions appear to be economic, not political. Even though Trump's policies may slow down the decline of coal, for example, long-term economic trends favour cheap gas and renewables (EIA, 2017).

In fact, this is true for a lot of countries. Progressive policies, technical innovation and greater economies of scale have pushed down the costs of low-carbon technologies. For example, the unit costs of solar photovoltaics dropped more than 60\% between 2009 and 2016, making it a cost-effective energy source in many parts of the world (UNEP, 2016). Thanks to falling costs and rising investment, renewables contributed almost two-thirds of the new power generation capacity added worldwide in 2016 (REN21, 2017). The growing share of renewables and improvements in energy efficiency are decoupling emissions from economic growth, with global energyrelated $\mathrm{CO}_{2}$ emissions being nearly flat in 2016 for the third consecutive year (IEA, 2017).

In short, US emissions are flat-lining and unlikely to increase because of the policies and actions of President Trump. However, this does not mean that the emission reduction goals of the Paris Agreement will be met. To level out the global average temperature increase at two degrees Celsius, much deeper cuts are needed than what is pledged in the NDCs (Rogelj et al., 2016).

\subsection{Retracted financing}

The most immediate threat of US non-cooperation for the Paris Agreement relates to climate finance. Although the importance of the US as an emitter is declining, it remains the largest and wealthiest economy among the industrialized countries. To gauge the impact of US non-cooperation, it is necessary to understand how large a role the US plays in providing public contributions to international initiatives for climate adaptation and mitigation.

According to the most recent numbers provided by the US government to the UNFCCC (USDS, 2016), the US delivered about US\$2.7 b per year in climate finance in 2013 and 2014. Large amounts of this funding came as loans or export credits. A much smaller chunk was provided to the World Bank or specialized UN funds and facilities. The US contribution is thus more than $10 \%$ of the total public climate finance that, according to estimates by the UNFCCC, flowed from developed to developing countries in 2013 and in 2014 (UNFCCC, 2016b). This is no small contribution for a single country to make, even when compared to other major bilateral donors. Germany donated US\$ 2.5 and 2.8 b in 2013 and 2014, respectively. France donated US\$ 3.0 and 3.7 b, while Japan donated US\$ 8.1 and 8.2 b.

The US alone has also pledged US\$ $3 \mathrm{~b}$ to the Green Climate Fund (GCF), which is the main financing tool of the UNFCCC. This would make the US the largest single contributor to the US\$ $10.3 \mathrm{~b}$ initial capitalization goal of the GCF but, to date, the US only delivered US\$ $1 \mathrm{~b}$. The new administration has made it amply clear that the remaining US\$ 2 b will not be deposited, jeopardizing about $20 \%$ of the Fund's current budget, and President 
Trump's proposed budget for 2018 would even stop funding the UNFCCC secretariat and the IPCC (White House, 2017a). ${ }^{7}$

At the 2009 Copenhagen conference, developed countries agreed to mobilize US\$100 b per year by 2020 to help developing countries cope with a changing climate and to help them bypass fossil-fueled development in favour of cleaner alternatives. This goal was reaffirmed in Paris. Without US financial contributions, it seems unlikely that other industrialized countries would be able to contribute enough to meet the goal. Even if private finance would - partially or wholly - close the gap, there is a chance that the poorest developing nations would be severely affected. That is because public bodies take on risk-return positions that a private investor would not bear. Public finance also includes initiatives to build governance capacity, cut down on corruption and develop infrastructure - in short, outcomes that do not offer an immediate return on investment, but are necessary pillars of a thriving economy. The poorest developing countries typically lack developed capital markets - e.g. a well-functioning banking system - requiring them to rely, instead, on international capital markets and, more specifically, development banks (Buchner, Falconer, Hervé-Mignucci, Trabacchi, \& Brinkman, 2011).

The pernicious effects of US non-cooperation on climate finance reach well beyond the immediate harm that reduced financial support for mitigation and adaptation does. Over time, US absence from climate finance would affirm the suspicion among least developed and emerging economies that the industrialized countries are untrustworthy because there is no firm domestic political consensus in favour of climate action. Thus, although we see no reason to worry about the immediate effects of US non-participation on pledge and review, in the long run the issue of climate finance could derail efforts to increase the ambition level of national mitigation plans so that the increase in global temperatures relative to pre-industrial times would more likely than not remain below two degrees Celsius. Indeed, both least developed and emerging economies tend to condition their ambition on external assistance in their NDCs (UNFCCC, 2016a), meaning that the lack of climate finance could reduce the ambition level of many important emitters. ${ }^{8}$

\section{Responses to US non-cooperation}

Based on the threat assessment above, we see two critical responses to US non-participation: leadership from emerging economies and domestic policies that insulate climate policies against electoral volatility and uncertainty.

\subsection{Climate leadership from emerging economies}

The abdication of climate leadership by the US creates the opportunity for other countries to step in and assume a leadership position. The European Union could fill the gap, as it did during the Bush years. Since the 2009 Copenhagen summit, where the EU had been barred from the key discussions, the EU has assumed the role of 'leadiator', combining traditional leadership with mediation between different parties (Bäckstrand \& Elgström, 2013; Oberthür \& Groen, 2017). As Europe's faith in the global moral, economic and security leadership of the US is fading, European countries are increasingly looking elsewhere for coalition partners (Schreurs, 2017).

They should look in the first place to deeper engagement with emerging economies, especially China and India. Emerging economies - by far the most important source of future emission growth - now face more pressure to engage in climate action than ever before. Equity concerns notwithstanding, the main development threatening to increase the rate of climate change is the rapid growth of emissions from emerging economies such as India. Fortunately, emerging economies increasingly recognize the benefits of climate action in terms of both domestic 'co-benefits' (Dubash, 2013) and international reputation. China, India and other emerging economies see value in clean energy sources, such as solar or wind power, and energy conservation as they strive to improve their energy security and reduce air pollution. An increase in climate policy ambition also fits well to the broader strategic goals of China and India. As both countries attempt to increase their soft power and influence in world politics, the gap left by US non-participation could be a strategic opportunity for the two countries to fill the leadership void. 
For years, countries such as China and India had objected to adopting commitments in the context of global climate negotiations until the developed countries had, as a whole, reduced their emissions. Since the 2009 Copenhagen summit, however, both countries have begun to make commitments to reduce the emission intensity of their GDP (Table 1). Both countries made it clear that their commitments were subject to the developed countries fulfilling their responsibilities with regard to financial and technology transfers under the UNFCCC (Gupta, 2016). Thus, China and India - along with many other rapidly growing economies - are offering to act on climate, but only if the industrialized countries support these efforts with financial assistance and transfers of clean technology. Again, we see the importance of climate finance.

China, which has played an important role in reducing the cost of renewable energy technology in world markets (PCT, 2009), could reap commercial benefits from deeper cooperation on decarbonization with other countries. At the same time, energy security plays a major role in China's energy strategy (Andrews-Speed, 2012), and investments in renewables and energy conservation contribute to achieving that goal. Responding to severe air pollution problems, China has already implemented ambitious policies to reduce its dependence on coal, resulting in a standstill in the construction of new coal-fired power plants (Shearer, Ghio, Myllyvirta, Yu, \& Nace, 2017). Since China's GDP growth is slowing down and the country is experiencing a structural shift away from heavy industry, it is highly plausible that the country's consumption of coal has effectively peaked (Qi, Stern, $\mathrm{Wu}, \mathrm{Lu}, \&$ Green, 2016) and its $\mathrm{CO}_{2}$ emissions might peak in the decade before 2025 (Green \& Stern, 2017). This new model of economic development at home is key to explaining China's transformation into a more constructive participant in the multilateral climate negotiations in the run-up to the 2015 Paris climate summit (Hilton \& Kerr, 2017). On the other hand, China continues to finance and construct coal-fired power plants in other countries, especially those that belong to General Secretary Xi Jinping's flagship One Belt, One Road Initiative (Peng, Chang, \& Liwen, 2017). Ending public support for coal-fired power generation capacity outside China thus presents a major opportunity for climate leadership for China.

India, on the other hand, faces serious energy security threats in the South Asian regional context (Singh, Jamasb, Nepal, \& Toman, 2015). Renewable energy is one way to reduce the country's dependence on imported fuels. India's own energy resources are very limited, as the only abundant domestic energy source is low-quality coal. The country also suffers from very high levels of air pollution in Delhi and many other urban areas. The Modi government's ambitious targets for renewable energy deployment - $175 \mathrm{GW}$ of capacity by 2022 (NITIAyog, 2015) - suggest an opportunity to find cleaner alternatives to coal in power generation, though implementation will present a momentous challenge. At the same time, India's June 2017 Draft National Energy Policy continues to assume that in the baseline scenario, India's coal-fired generation capacity will more than double from less than 200 to over $440 \mathrm{GW}$ by the year 2040 (NITI-Ayog, 2017). Under rapidly falling renewable power generation prices, India can claim climate leadership by making a clear commitment to focusing on alternatives to coal.

Against this backdrop, US non-cooperation presents an opportunity for deeper engagement of the EU with emerging economies. One noteworthy development in this regard is the decision by China and the EU to strengthen their climate cooperation as well as to work jointly to implement and strengthen the Paris Agreement (European Commission, 2017). Together with Canada, these parties held a ministerial climate summit back-to-back to an IPCC meeting in early September 2017 to advance the goals of Paris. India and France have already taken the lead in setting up an International Solar Alliance during COP21 in Paris. During the G20 leaders' summit in July 2017, the US was totally isolated as the final communique read: 'We take note of the decision of the United States of America to withdraw from the Paris Agreement.' It added: 'The leaders of the other G20 members state that the Paris Agreement is irreversible' $(G 20,2017)$.

Setting up new institutions and isolating the US can be seen as examples of entrepreneurial leadership. While important, the litmus test of these initiatives ultimately remains implementation. For any of these countries to

Table 1. Copenhagen and Paris pledges: China and India.

\begin{tabular}{llcc}
\hline & \% cut in carbon intensity ... & China & India \\
\hline Copenhagen pledges & $\ldots$ between 2005 and 2020 & $40-45 \%$ & $20-25 \%$ \\
Paris pledges & $\ldots$ between 2005 and 2030 & $60-65 \%$ & $33-35 \%$ \\
\hline
\end{tabular}


claim a directional leadership position in tackling climate change, their national mitigation goals need to be strengthened. Taking into account various equity concepts, one study found that the EU's domestic 2030 reduction target would have to be more than doubled ( $61 \%$ instead of $27 \%$ below 2010 by 2030). The percentage gap is even higher for China's goal to peak fossil $\mathrm{CO}_{2}$ emissions by 2030 compared to 2010 (Meinshausen et al., 2015; see also du Pont et al., 2017).

In contrast, punitive measures such as border tax adjustments against the US (an example of power-based leadership) are unlikely to play a constructive role, as they would threaten to trigger a trade war and thus undermine the interests of key emerging economies in the long run. Indeed, Böhringer \& Rutherford (2017) find that

[g]iven the possibility of retaliatory tariffs across all imported goods, carbon tariffs do not constitute a credible threat for the US. A tariff war with its main trading partners China and Europe might make the US worse off than compliance to the Paris Agreement but China, in particular, should prefer US defection to a tariff war.

\subsection{Dealing with domestic political uncertainty}

The other important response to US non-cooperation is to proof the Paris Agreement against domestic political uncertainty. Although the Trump presidency was a great surprise to many commentators, there has always been a strong undercurrent against progressive climate policies in the US. This is probably the reason why the Obama administration pushed so hard during the negotiations to design the Paris Agreement in a way that would allow it to bypass Senate ratification and simply 'accept' the accord through an Executive Order (Wirth, 2016). Trump's electoral victory is also part of a broad populist wave across the globe. Another important case is Brexit, the British referendum on leaving the European Union. These domestic political shocks call into question the assumption that the world can now count on key industrialized and emerging economies to maintain unanimous support for climate action. The consensus on climate action appears to be restricted to mainstream political parties. To protect the Paris Agreement from domestic political turmoil, it is thus important to consider domestic strategy.

One strategy to achieve this goal would be to lock-in climate policies as they are developed, so that they are resilient to electoral cycles and shocks. To some extent, this could be achieved through litigation and courts. In constitutional democracies such as the US, there are already several legal guardrails in place that prevent a quick dismantling of existing climate policies. However, the strategy of litigation faces strict limits as its success depends considerably on individual country constituents and legal precedent. Moreover, litigation cuts both ways. Trump's Executive Order of March 2017 is currently facing legal challenges from environmentalists, just as Obama's Clean Power Plan was challenged in courts.

A more promising strategy is the targeted expansion of the domestic political coalition in favour of climate action. This can be achieved through green industrial policies that offer significant benefits to a small group of economic actors, while imposing only moderate costs on society (e.g. renewable fuel standards, feed-in tariffs, subsidies, etc.). For example, one very important policy that the Trump presidency is not targeting is the federal production tax credit for renewable energy. This tax credit generates direct benefits to many Republican electoral districts, and thus the policy enjoys broad bi-partisan support in Congress. Such policies are politically resilient because their beneficiaries will be disproportionately motivated to lobby for or defend them in the political process (Jenkins, 2014).

Economists generally regard such targeted policies that concentrate benefits in a visible way as less efficient than carbon pricing, because they tend to have a very high cost per ton of greenhouse gas emissions they abate (e.g. Nordhaus, 1992; Stavins, 1997). But research in political science suggests that targeted, sector-specific policies bring new economic constituencies into coalitions for decarbonization, while neutralizing opposition from carbon-intensive industries (Aklin \& Urpelainen, 2013; Meckling, Kelsey, Biber, \& Zysman, 2015). In domestic politics, such a favourable constituency is particularly important at a time when climate policy itself could fall prey to electoral populism.

There are also ways to increase the electoral resilience even of such policies (like carbon taxes) that have no direct private beneficiaries, beyond the general social benefits of climate mitigation. The creative use of 
revenues from carbon taxes can help to cement the political acceptability of such a tax and increase its environmental efficacy, for instance when the revenues are used to support clean energy research and development (Fischer, 2008). A related strategy is an increased emphasis on co-benefits that benefit interest groups across the board, and that are salient to citizens and voters. Even though climate change is a bete noire for many conservatives and the fossil fuel industry, broad swaths of the public benefit from such co-benefits as green jobs and improved air quality (Nemet, Holloway, \& Meier, 2010). Focusing on near-term benefits could help to close the temporal and geographic mismatch between mitigation costs and benefits (Jenkins, 2014).

In creating a domestic political constituency for climate action, it is important to avoid fuelling the fires of partisan polarization over the issue. As Nordhaus \& Trembath (2017) note, Trump's decision to withdraw from the Paris Agreement had a domestic audience of Republicans who consider climate change an anathema. If domestic climate policies are owned by one political party or movement at the expense of others, it is possible that domestic uncertainties are actually compounded. In a less polarized environment, for example, Trump might have not withdrawn from the Paris Agreement. We thus caution against overly partisan and polarizing strategies to expand the climate advocacy coalition. If the goal is to reduce domestic political uncertainty, activities that have broad popular support are more effective. One example might be clean technology innovation.

Domestic entrenchment may also be fostered through non-state and community action on climate change. Since November 2016, more than one thousand companies and investors have urged President Trump to uphold the goals of the Paris Agreement. The signatures include major companies such as Nike, Unilever and DuPont. ${ }^{9}$ They were joined by companies such as Google, Facebook, Intel and Microsoft, and oil companies BP and Shell, which sent a letter to President Trump in April 2017, expressing their support for continued participation by the US in the Paris Agreement. ${ }^{10}$ These voices show that there is a strong business case to be made for climate policies, especially for the IT, high tech, entertainment and retail industries, where carbon constraints do not threaten to significantly diminish profit margins, and where the customer base tends to directly reward green and corporate social responsibility (CSR) initiatives. Such a coalition of business actors in favour of decarbonization can reduce uncertainty about climate policy if it is powerful enough to counter the influence of those sectors that expect to lose from carbon constraints, such as the coal sector and heavy, energy-intensive industries.

Strengthening state, municipal, local and community-owned energy projects, finally, could further build support and insulate climate policies from electoral cycles. Sub- and non-state actions not just hold the promise of helping to advance the goals of the Paris Agreement, but also to deliver policy innovation, experimentation, demonstration effects and best practices that can diffuse transnationally (Chan et al., 2015). While there is no guarantee that these benefits will be realized, Betsill (2017) notes that the response to President Trump's withdrawal from the Paris Agreement has been qualitatively different from the reaction when President George W. Bush rejected the Kyoto Protocol in 2001, implying that, in certain respects, a global normative shift has occurred and a strong non-state constituency exists that supports ambitious climate policy.

\section{Conclusion}

The US is no longer the pivotal player it used to be in climate policy, but President Trump's non-cooperation remains a significant threat to the Paris Agreement nonetheless. We are optimistic about the robustness of the pledge-and-review approach to ratcheting up the commitments of different countries, but we see climate finance as a potential victim of Trump's hostility to global climate cooperation. Climate finance is important for the big picture because it can build trust between industrialized, emerging and developing countries. If US non-participation compromises climate finance, then the most important antidote is for industrialized countries to engage with emerging economies by other means.

More generally, Trump's victory, which surprised many, calls into question the idea that domestic politics no longer raises barriers to climate cooperation. The rise of right-wing populist parties in the industrialized world and elsewhere opens a window of opportunity for interest groups that oppose climate policy, as one of the key tenets of contemporary (right-wing) populism is a profound distrust of experts and elites. Multilateral climate accords such as the Paris Agreement are often portrayed as part of the 'establishment' that populist voices are keen to overthrow. A key lesson from Trump's climate non-policy is the importance of building broad 
coalitions that benefit from climate policies - regardless of whether or not they are called that, or something else, in the public discourse.

To be sure, compensating for the lack of US leadership is not going to be easy. In the absence of decisive American or European leadership, China and India have good reasons to remain cautious second-movers even though they are less opposed to climate mitigation than in the past. One way to solve these problems could be a trilateral climate agreement among the European Union, China and India with a heavy emphasis on co-benefits, commercial opportunities and energy security from low-carbon technologies.

\section{Notes}

1. Notably, though, the Trump administration has not discussed the possibility of withdrawing from the United Nations Framework Convention on Climate Change (UNFCCC).

2. See http://www.sueddeutsche.de/politik/afd-minuszuwanderung-und-ausstieg-aus-allen-klimaschutzorganisationen-1. 3412470 (accessed May 5, 2017).

3. See http://inthesetimes.com/article/18676/trump_le_pen_front_national_paris_climate_change_talks_and_econationalism (accessed May 5, 2017).

4. It should be noted that the Obama administration also oversaw the construction of new export terminals for liquefied natural gas and lifted the 40-year-old crude oil export embargo. The effects of natural gas exports on the climate are complex and depend on whether the exports displace coal or low-carbon energy sources, such as nuclear and wind power (Newell \& Raimi, 2014). Repealing the oil export ban, in turn, was part of a package deal that included an extension of tax credits for wind and solar energy (Colgan \& Van de Graaf, 2017).

5. Another possible problem is US obstructionism in the negotiations. However, we focus here instead on the direct effects of non-cooperation on other countries' incentives to act.

6. IMF, World Economic Outlook Database, April 2017. US Department of Commerce, Bureau of Economic Analysis, GDP by state, April 2017.

7. The Trump administration's cuts to funding for domestic climate research is a related problem.

8. Similarly, a lack of US funding for the UNFCCC and IPCC could compromise the implementation of the Paris Agreement.

9. The list of signatories is available at: http://lowcarbonusa.org/business.

10. Letter available from: https://www.c2es.org/docUploads/business-letter-white-house-paris-agreement-final-04-26-2017.pdf.

\section{Acknowledgments}

We thank participants of a roundtable on international energy governance at the Vanderbilt Law School (28-29 April 2017), three anonymous reviewers and Joanna Depledge for thoughtful comments on a previous draft.

\section{Disclosure statement}

No potential conflict of interest was reported by the authors.

\section{ORCID}

Thijs Van de Graaf (D) http://orcid.org/0000-0003-3372-3830

\section{References}

Aklin, M., \& Urpelainen, J. (2013). Political competition, path dependence, and the strategy of sustainable energy transitions. American Journal of Political Science, 57(3), 643-658.

Andresen, S., \& Agrawala, S. (2002). Leaders, pushers and laggards in the making of the climate regime. Global Environmental Change, 12(1), 41-51.

Andrews-Speed, P. (2012). The governance of energy in China: Transition to a low carbon economy. New York: Palgrave Macmillan. Bäckstrand, K., \& Elgström, O. (2013). The EU's role in climate change negotiations: From leader to 'leadiator'. Journal of European Public Policy, 20(10), 1369-1386.

Bang, G., Hovi, J., \& Sprinz, D. F. (2012). US presidents and the failure to ratify multilateral environmental agreements. Climate Policy, 12 (6), 755-763. 
Bang, G., \& Schreurs, M. A. (2016). The United States: The challenge of global climate leadership in a politically divided state. In R. K. Wurzel, J. Connelly, \& D. Liefferink (Eds.), The European Union in international climate change politics: Still taking a lead? New York, NY: Routledge.

Barbose, G., Wiser, R., Heeter, J., Mai, T., Bird, L., Bolinger, M., \& Millstein, D. (2016). A retrospective analysis of benefits and impacts of US renewable portfolio standards. Energy Policy, 96, 645-660.

Betsill, M. M. (2017). Trump's Paris withdrawal and the reconfiguration of global climate change governance. Chinese Journal of Population Resources and Environment, 15, 189-191. doi:10.1080/10042857.2017.1343908:1-3

Böhringer, C., \& Rutherford, T. F. (2017). Paris after Trump: An inconvenient insight (ZenTra Working Paper in Transnational Studies, 72/ 2017).

Bomberg, E. (2017). Environmental politics in the Trump era: An early assessment. Environmental Politics, 26, $956-963$.

Bordoff, J. (2017). Withdrawing from the Paris climate agreement hurts the US. Nature Energy, 2, 17145.

Buchner, B., Falconer, A., Hervé-Mignucci, M., Trabacchi, C., \& Brinkman, M. (2011). The landscape of climate finance. Climate Policy Initiative, Venice, 27.

CAT (2017). Trump's climate policies would see US climate action rating drop from 'medium' to 'inadequate'. Climate Action Tracker.

Chan, S., van Asselt, H., Hale, T., Abbott, K. W., Beisheim, M., Hoffmann, M., \& Widerberg, O. (2015). Reinvigorating international climate policy: A comprehensive framework for effective nonstate action. Global Policy, 6(4), 466-473.

Clémençon, R. (2008). The Bali road map: A first step on the difficult journey to a post-Kyoto Protocol agreement. Journal of Environment and Development, 17(1), 70-94.

Climate Action Tracker (2017a). Australia.

Climate Action Tracker (2017b). USA.

Colgan, J. D., \& Van de Graaf, T. (2017). A crude reversal: The political economy of the United States crude oil export policy. Energy Research \& Social Science, 24, 30-35.

De Coninck, H., Fischer, C., Newell, R. G., \& Ueno, T. (2008). International technology-oriented agreements to address climate change. Energy Policy, 36(1), 335-356.

Depledge, J. (2005). Against the grain: The United States and the global climate change regime. Global Change, Peace \& Security, 17(1), 11-27.

DeSombre, E. R. (2000). Domestic sources of international environmental policy: Industry, environmentalists, and US power. Cambridge, MA: Mit Press.

Dimitrov, R. S. (2016). The Paris agreement on climate change: Behind closed doors. Global Environmental Politics, 16, 1-11.

du Pont, Y. R., Jeffery, M. L., Gütschow, J., Rogelj, J., Christoff, P., \& Meinshausen, M. (2017). Equitable mitigation to achieve the Paris agreement goals. Nature Climate Change, 7(1), 38-43.

Dubash, N. K. (2013). The politics of climate change in India: Narratives of equity and cobenefits. Wiley Interdisciplinary Reviews: Climate Change, 4(3), 191-201.

Eckersley, R. (2007). Ambushed: The Kyoto protocol, the Bush administration's climate policy and the erosion of legitimacy. International Politics, 44(2-3), 306-324.

EIA (2017). Annual energy outlook 2017. U.S. Energy Information Administration.

Environment and Climate Change Canada (2017, September 9). Canada doubles funding for leading international body for climate change science. Government of Canada. Retrieved from goo.gl/XbezCK.

European Commission (2017). EU-China summit: Moving forward with our global partnership.

Falkner, R. (2016). The Paris agreement and the new logic of international climate politics. International Affairs, 92(5), 1107-1125.

Feng, K., Davis, S. J., Sun, L., \& Hubacek, K. (2015). Drivers of the US $\mathrm{CO}_{2}$ emissions 1997-2013. Nature Communications, 6. doi:10.1038/ ncomms 8714

Fischer, C. (2008). Emissions pricing, spillovers, and public investment in environmentally friendly technologies. Energy Economics, 30 (2), 487-502.

G20 (2017). G20 leaders' declaration: Shaping an interconnected world (Technical report). Hamburg.

Galik, C. S., Decarolis, J. F., \& Fell, H. (2017). Evaluating the US mid-century strategy for deep decarbonization amidst early century uncertainty. Climate Policy, 17, 1046-1056.

Ghosh, A., \& Woods, N. (2009). Developing country concerns about climate finance proposals: Priorities, trust, and the credible donor problem. In R. B. Stewart, B. Kingsbury, \& B. Rudyk (Eds.), Climate finance: Regulatory and funding strategies for climate change and global development (pp. 157-164). New York: New York University Press.

Green, F., \& Stern, N. (2017). China's changing economy: Implications for its carbon dioxide emissions. Climate Policy, 17(4), 423-442.

Greenblatt, J. B., \& Wei, M. (2016). Assessment of the climate commitments and additional mitigation policies of the United States. Nature Climate Change, 6, 1090-1093.

Gupta, J. (2016). The Paris climate change agreement: China and India. Climate Law, 6(1-2), 171-181.

Hale, T. (2011). A climate coalition of the willing. Washington Quarterly, 34(1), 89-101.

Harrison, K. (2007). The road not taken: Climate change policy in Canada and the United States. Global Environmental Politics, 7(4), 92-117.

Hausfather, Z. (2017). Analysis: Why US carbon emissions have fallen 14\% since 2005. Retrieved from https://www.carbonbrief.org/ analysis-why-us-carbon-emissions-have-fallen-14-since-2005

Hilton, I., \& Kerr, O. (2017). The Paris agreement: China's 'new normal' role in international climate negotiations. Climate Policy, 17(1), 48-58. 
Hoffmann, M. J. (2011). Climate governance at the crossroads: Experimenting with a global response after Kyoto. New York, NY: Oxford University Press.

IEA (2017). IEA finds $\mathrm{CO}_{2}$ emissions flat for third straight year even as global economy grew in 2016.

Jenkins, J. D. (2014). Political economy constraints on carbon pricing policies: What are the implications for economic efficiency, environmental efficacy, and climate policy design? Energy Policy, 69, 467-477.

Kemp, L. (2016). Bypassing the 'ratification straitjacket': Reviewing US legal participation in a climate agreement. Climate Policy, 16(8), 1011-1028.

Kemp, L. (2017a). Better out than in. Nature Climate Change, 7(7), 458-460.

Kemp, L. (2017b). US-proofing the Paris climate agreement. Climate Policy, 17(1), 86-101.

Keohane, R. O., \& Victor, D. G. (2011). The regime complex for climate change. Perspectives on Politics, 9(01), 7-23.

Lesage, D., Van de Graaf, T., \& Westphal, K. (2010). Global energy governance in a multipolar world. Farnham: Ashgate.

Meckling, J., Kelsey, N., Biber, E., \& Zysman, J. (2015). Winning coalitions for climate policy. Science, 349(6253), $1170-1171$.

Mehling, M. A. (2017). A new direction for us climate policy: Assessing the first 100 days of Donald Trump's presidency. Carbon and Climate Law Review, 2017(1). Retrieved from https://papers.ssrn.com/sol3/papers.cfm?abstract_id=2960715

Meinshausen, M., Jeffery, L., Guetschow, J., Du Pont, Y. R., Rogelj, J., Schaeffer, M., \& Meinshausen, N. (2015). National post-2020 greenhouse gas targets and diversity-aware leadership. Nature Climate Change, 5(12), 1098-1106.

Nemet, G. F., Holloway, T., \& Meier, P. (2010). Implications of incorporating air-quality co-benefits into climate change policymaking. Environmental Research Letters, 5(1), 014007.

Newell, R. G., \& Raimi, D. (2014). Implications of shale gas development for climate change. Environmental Science and Technology, 48 (15), 8360-8368.

NITI-Ayog (2015). Report of the expert group on 175 GW RE by 2022. New Delhi: National Institution for Transforming India.

NITI-Ayog (2017). Draft national energy policy for public comments. New Delhi: Government of India.

Nordhaus, T., \& Trembath, A. (2017, June). Trump's Paris agreement withdrawal in context. Foreign Affairs.

Nordhaus, W. D. (1992). An optimal transition path for controlling greenhouse gases. Science, 258, 1315-1319.

Oberthür, S., \& Groen, L. (2017). The European Union and the Paris agreement: Leader, mediator, or bystander? Wiley Interdisciplinary Reviews: Climate Change, 8(1). doi:10.1002/wcc.445

Paterson, M. (2009). Post-hegemonic climate politics? British Journal of Politics and International Relations, 11(1), $140-158$.

PCT (2009). Who's winning the clean energy race? Growth, competition and opportunity in the world's largest economies. Washington DC: Pew Charitable Trusts.

Peng, R., Chang, L., \& Liwen, Z. (2017). China's involvement in coal-fired power projects along the Belt and Road. Beijing: Global Environmental Institute.

Qi, Y., Stern, N., Wu, T., Lu, J., \& Green, F. (2016). China's post-coal growth. Nature Geoscience, 9(8), 564-566.

Rabe, B. (2004). Statehouse and greenhouse: The evolving politics of American climate change policy. Washington, DC: Brookings Institution Press.

REN21 (2017). Renewables 2017: Global status report (Technical report). REN21.

Rogelj, J., Den Elzen, M., Höhne, N., Fransen, T., Fekete, H., Winkler, H., \& Meinshausen, M. (2016). Paris agreement climate proposals need a boost to keep warming well below $2^{\circ} \mathrm{C}$. Nature, 534(7609), 631-639.

Sanderson, B. M., \& Knutti, R. (2016). Delays in US mitigation could rule out Paris targets. Nature Climate Change, 7(2), 92-94. doi:10. 1038/nclimate3193

Schreurs, M. (2017). The European Union and the Paris climate agreement: Moving forward without the United States. Chinese Journal of Population Resources and Environment, 15(3), 192-195.

Schreurs, M. A., \& Tiberghien, Y. (2007). Multi-level reinforcement: Explaining European Union leadership in climate change mitigation. Global Environmental Politics, 7(4), 19-46.

Shearer, C., Ghio, N., Myllyvirta, L., Yu, A., \& Nace, T. (2017). Boom and bust 2017: Tracking the global coal plant pipeline. Sierra Club, Greenpeace, CoalSwarm. https://endcoal.org/wp-content/uploads/2017/03/BoomBust2017-English-Final.pdf

Singh, A., Jamasb, T., Nepal, R., \& Toman, M. (2015). Cross-border electricity cooperation in South Asia. World Bank Group, Policy Research Working Paper 7328.

Skodvin, T., \& Andresen, S. (2006). Leadership revisited. Global Environmental Politics, 6(3), 13-27.

Skodvin, T., \& Andresen, S. (2009). An agenda for change in US climate policies? Presidential ambitions and congressional powers. International Environmental Agreements: Politics, Law and Economics, 9(3), 263-280.

Stavins, R. N. (1997). Policy instruments for climate change: How can national governments address a global problem. University of Chicago Legal Forum, p. 293.

UNEP (2016). Global trends in renewable energy investment 2016 (Technical report). Frankfurt School-UNEP Collaborating Centre for Climate and Sustainable Energy Finance and Bloomberg New Energy Finance.

UNFCCC (2016a). Aggregate effect of the intended nationally determined contributions: An update. United Nations Framework Convention on Climate Change, FCCC/CP/2016/2.

UNFCCC (2016b). Summary and recommendations by the standing committee on finance on the 2016 biennial assessment and overview of climate finance flows. United Nations Framework Convention on Climate Change.

United States (2015). Intended nationally determined contribution. Washington, DC: UNFCCC.

Urpelainen, J. (2009). Explaining the Schwarzenegger phenomenon: Local frontrunners in climate policy. Global Environmental Politics, 9(3), 82-105. 
Urpelainen, J. (2011). Can unilateral leadership promote international environmental cooperation? International Interactions, 37(3), 320-339.

USDS (2016). Second biennial report of the United States of America under the United Nations Framework Convention on Climate Change. U.S. Department of State.

Weber, C. L., \& Peters, G. P. (2009). Climate change policy and international trade: Policy considerations in the US. Energy Policy, 37(1), 432-440.

White House (2014). Fact sheet: US-China joint announcement on climate change and clean energy cooperation.

White House (2016). United States mid-century strategy for deep decarbonization. Washington DC.

White House (2017a). America first: A budget blueprint to make America great again. Office of Management and Budget, White House.

White House (2017b). Presidential executive order on promoting energy independence and economic growth. Executive order 13783 of 28 March 2017.

Wirth, D. A. (2016). Cracking the American climate negotiators' hidden code: United States law and the Paris agreement. Climate Law, 6 (1-2), 152-170.

WRI (2017). CAIT climate data explorer. Washington, DC: World Resources Institute.

Young, O. R. (1991). Political leadership and regime formation: On the development of institutions in international society. International Organization, 45(3), 281-308. 